\title{
OPTIMALISASI PARTISIPASI ORANG TUA MELALUI PROGRAM PARENTING DI LEMBAGA PAUD SRIKANDI
}

\author{
Oom Saromah'1, Prita Kartika² \\ 1, 2 IKIP Siliwangi \\ ${ }^{1}$ oomsyaromah@gmail.com
}

\begin{abstract}
ABSTRAK
Seiring dengan peningkatan jumlah satuan PAUD saat ini menyebabkan penuruanan jumlah siswa pada PAUD Srikandi yakni pada tahun 2015 berjumlah 36 siswa, 2016 berjumlah 22 siswa dan pada tahun 2017 dan 2018 berjumlah 16 siswa. Hal ini mengindikasikan masih banyak ketidakseimbangan dengan upaya pengoptimalan lembaga PAUD, diantaranya adalah kurangnya partisispasi orang tua. Sedangkan partisipasi orangtua terhadap pendidikan PAUD sangatlah berpengaruh terhadap anak, dan keberlangsungan lembaga PAUD. Tujuan penelitiannya untuk mengetahui: (1) Bagaimana strategi pengelola lembaga untuk mengoptimalisasikan partisispasi orangtua melalui program parenting? (2) Bagaimana bentuk program yang digunakan pengelola untuk mengoptimalisasikan partsisipasi melalui program parenting? (3) Bagaimana hasil yang diperoleh dengan adanya optimalisasi partisipasi orang tua melalui program parenting? program parenting diperuntukkan bagi orang dewasa dalam lingkungan masyarakatnya, agar mereka dapat mengembangkan kemampuan, memperkaya pengetahuan, meningkatkan keterampilan dan profesi yang telah dimiliki, memperoleh cara-cara baru, serta mengubah sikap dan perilaku orang dewasa dan anak. Metode yang digunakan pada penelitian ini adalah metode kualitatif melalui teknik pengumpulan data yaitu observasi, wawancara dan angket. Adapun yang menjadi populasi dalam penelitian ini adalah seluruh orang tua siswa sebanyak 16 orang, pengelola, serta tutor. Lokasi penelitian ini di lakukan di PAUD Srikandi. Hasil yang diraih dari penelitian ini adalah partisipasi orang tua terhadap program yang di selenggerakan lembaga PAUD dinilai masih sangat kurang sehingga terdapat upaya pengelola untuk mengoptimalkan partisipasi orang tua melalui beberapa strategi diantaranya mengadakan keterampilan tataboga yang di lakukan oleh para turtor dan pengelola, serta meningkatkan kompetensi guru melalui pelatihan, namun orangtua tetap kurang berpartisipasi dikarenakan faktor jarak dan kesempatan waktu.
\end{abstract}

Kata kunci : Partisipasi Orangtua, Parenting, PAUD

\section{A. PENDAHULUAN}

Pendidikan anak usia dini adalah stimulasi bagi masa yang penuh dengan kejadian penting dan unik yang meletakan dasar bagi seseorang dimasa dewasa (Suyadi : 16). Pengalaman-pengalaman tersebut tidak bisa tergantikan oleh pengalaman-pengalaman yang berikutnya, karena pengalaman belajar dan pengembangan awal merupakan dasar 
bagi proses belajar dan perkembangan selanjutnya. Oleh karena itu pendidikan anak usia dini sangatlah penting karena kekeliruan belajar pada anak usia dini bisa menjadi penghambat bagi proses belajar pada usia-usia selanjutnya

Pendidikan anak usia dini pada hakikatnya ialah pendidikan yang diselenggerakan dengan tujuan untuk memfasilitasi pertumbuhan dan perkembangan anak secara menyeluruh atau menekankan pada pengembangan seluruh aspek keperibadian anak (Suyadi : 17). Jadi PAUD memberikan kesempatan dan kebabasan kepada anak-anak untuk dapat mengembangkan potensi yang dimiliknya secara maksimal. Sehingga lembaga PAUD perlu menyediakan berbagai kegiatan yang dapat mengembangkan berbagai aspek perkembangan anak, seperti aspek kognitifnya, afektif dan psikomotoriknya. Semua aspek tersebut sangat dibutuhkan anak saat masa perkembangannya. Dan untuk mengembangkan beberapa aspek tersebut di perlukan peran dari beberapa pihak yang mendukung perkembangan anak tersebut, yaitu lembaga PAUD itu sendiri, orangtua dan keluarga serta masyarakat.

Setiap orangtua pasti menginginkan tujuan yang sama, yakni menginginkan anaknya dapat tumbuh dan berkembang secara maksimal, berakhlah dan berbudi perkerti luhur sehingga di harapkan kedepannya dapat produktif dan mandiri.

Untuk dapat mencapai tujuan akhir seperti yang diharapkan tersebut, makan orangtua sangatlah berpengaruh dan bertanggung jawab penuh terhadap proses pembelajaran dan tumbuh kembang anak. Kemudian dalam membantua anak agar tumbuh dan berkembang secara maksimal tidak harus dengan memiliki gelar khusus ataupun latihan khusus, tapi cukup dengan mendidik penuh kasih sayang, keikhlasan, serta kesabaran dan hanya bertujuan untuk mencapai ridho allah saja lah untuk memberikan pertimbangan terbaik dalam setiap kebijakan-kebijakan penting didalam kehidupan dan proses tumbuh kembang anak.

Tujuan Pendidikan anak usia dini menurut Suyanto (Suyadi :19) menyatakan bahwa tujuan PAUD adalah untuk mengembangkan seluruh potensi anak agar kelak dapat berfungsi sebagai manusia utuh sesuai falsafah suatu negara. Manusia utuh jika dilihat dalam pandangan islam biasa disebut insan kamil atau manusia sempurna. Manusia sempurna ialah manusia yang terpelihara fitrah dalam dirinya, karena sejatinya setiap anak membawa fitrah positifnya masing masing, artinya anak itu ketika lahir kedunia dianggap sebagai individu yang tak tau apa-apa, sehingga anak perlu dibimbing untuk memahami berbagai hal tentang dunia dan isinya dan dalam proses bimbingan inilah orangtua sangatlah berperan.

Jadi, dapat disimpulkan bahwa tujuan pendidikan anak usia dini tersebut adalah untuk membimbing setiap anak agar mampu tumbuh dan berkembang sesuai dengan yang diharapkan. Perkembangan ini tentu sangat positif jika dilihat dari sisi perluasan akses layanan pendidikan (Juknis penyelenggaraan PAUD : 5). Jumlah sekolah untuk enam jenjang (TK, SD, SLB, SMP, SM dan PT) pada tahun 2008/2009 sebesar 259.644 dan pada tahun 2013/2014 meningkat menjadi 289.044 atau 2,17\% per tahun (ida kintamani, 2015). Seiring dengan peningkatan jumlah satuan PAUD tersebut diindikasikan PAUD Srikandi mengalami penurunan peserta didik, dilihat dari dari hasil penelitian secara empiris bahwa pada tahun 2015/2016 jumlah peserta didik 36 siswa, 
tahun 2016/2017 jumlah perta didik 22 siswa dan terakhir pada tahun ajaran 2017/2018 berjumlah 16 siswa. Dari data tersebut dapat dilihat bahwa partisipasi orangtua dirasa kurang terhadap PAUD Srikandi. Sedangkan partisipasi orangtua sangatkah berpengaruh terhadap suatu PAUD. PAUD Srikandi pun telah melakukan optimalisasi PAUD dengan beberapa kegiatan, salah satu kegiatannnya adalah melalui program parenting. Jadi berdasarkan permasalahan tersebut peneliti tertarik untuk mengangkat judul penelitian "Optimalisasi partisipasi orangtua melalui program Parenting di PAUD Srikandi".

\section{B. KAJIAN TEORI}

\section{Konsep Parenting}

a. Pengertian parenting

Program Program pendidikan keorangtuan atau program parenting termasuk kedalam pendidikan orang dewasa, yang dimana pendidikan orang dewasa menurut (Sudjana, 2010, hlm. 45) yaitu diperuntukkan bagi orang dewasa dalam lingkungan masyarakatnya, agar mereka dapat mengembangkan kemampuan, memperkaya pengetahuan, meningkatkan keterampilan dan profesi yang telah dimiliki, memperoleh cara-cara baru, serta mengubah sikap dan perilaku orang dewasa.

Program parenting adalah program dukungan yang ditunjukan kepada para orang tua atau anggota keluarga yang lain agar semakin memiliki kemampuan dalam melaksanakan fungsi sosial dan pendidikan dalam hal mengasuh, merawat, melindungi, dan mendidik anaknya di rumah sehingga anak dapat tumbuh dan berkembang secara optimal, sesuai dengan usia dan tahap perkembangannya (Juknis Orientasi Teknis Peningkatan Program Parenting tahun 2011).

Manfaat kegiatatan parenting, yaitu dapat membangun komunikasi yang baik antara lembaga dengan orangtua. Sehingga pola pengasuhan yang dijalankan di lembaga dengan yang diterapkan orang tua dirumah selaras, melalui kegiatan parenting juga orangtua dapat mengetahui capaian perkembangan anak, hak-hak dasar apa saja yang harus dipenuhi orangtua dalam kelangsungan hidup anak, dan memberikan pengetahuan kepada orangtua. selain itu dengan adanya program parenting juga khusus bagi para ibu-ibu itu merupakan salah satu bentuk dari pemberdayaan perempuan. Sesuai dengan sasaran program pemberdayaan perempuan secara umum yaitu, pertama dalah meningkatnya kualitas sumberdaya perempuan diberbagai kegiatan sektor dan subsektor serta lembaga dan non lembaga yang mengutamakan peningkatan kemampuan dan profesionalisme atau keahlian kaum perempuan (Novi widiastuti, Prita Kartika : Jurnal empowerment Vol 6, nomor 2 Oktober 2017)

\section{Konsep Partisipasi}

\section{a. Pengertian Partisipasi}

H.A.R.Tilaar, (2009: 287) mengungkapkan partisipasi adalah sebagai wujud dari keinginan untuk mengembangkan demokrasi melalui proses desentralisasi dimana diupayakan antara lain perlunya perencanaan dari bawah (bottom-up) dengan mengikutsertakan masyarakat dalam proses perencanaan dan pembangunan masyarakatnya. Mengikitsertakan masyarakat atau orangtua dalam proses perencanaan 
merupakan hal yang penting yang bertujuan untuk memberi pengetahuan dan informasi kepada masyarakat atau orangtua terhadap hal apa saja yang akan dilakukan sehingga orangtua mampu menyampaikan ide dyang muncul dan informasi terhadap kemungkinan terjadinya beberapa masalah, artinya partisipasi adalah keikutsertaan masyarakat dalam memecahkan suatu permasalahan dalam bentuk penyampaian saran dan pendapat, barang, keterampilan, bahan dan jasa ataupun yang lainnya yang bisa di sampaikan kepada pihak lembaga.

Selain itu partisipasi orangtua terhadap lembaga juga bisa berupa pengawasan dan bimbingan terhadap anak-anaknya dirumah, karena bagaimanapun juga rumah merupakan madrasah atau sekolah pertama bagi seorang anak. Hal ini berimplikasi bahwa orangtua merupakan guru pertama bagi anak, termasuk kakek, nenek, dan orangtua yang lebih dewasa dalam rumah tersebut termasuk kedalam guru pertama bagi anak.

Kemudian dalam hal ini lembaga PAUD-lah yang harus mensosialisasikan programprogram pendidikannya agar selaras dengan kegiatan anak dirumah, hal ini dimaksudkan agar kegiatan dirumah tidak bertentangan dengan kegiatan di sekolah PAUD. Salah satu bentuk sosialisasi yang dapat dilakukan adalah dengan mengadakan pertemuan bulanan (parenting) yang dihadiri oleh masyarakat sekitar wali murid serta para guru PAUD itu sendiri.

Dengan penyelarasan persepsi antara kegiatan di rumah dan program PAUD maka tumbuh kembang anak akan berjalan dengan efektif, jadi atas dasar inilah berhasil atau tidaknya lembaga PAUD dalam mencerdaskan anak didiknya tergantung pada efektivitas rumahnya sebagai sekolah pertama dan utama bagi anak, karena kebanyakan waktu bermain dan aktifitas lainnya di habiskan di rumah, daripada waktu belajarnya disekolah.

Selanjutnya, efektivitas rumah sebagai sekolah pertama bagi anak tidak hanya ditentukan oleh persamaan persepsi antara orangtua dan PAUD semata, tetapi ditentukan juga oleh hubungan yang harmonis antara ayah dan ibu (suami istri) serta orang-orang yang ada didalamnya (Suyadi :150). Jadi tak jarang anak yang orangtuanya mengalama broken home merka sulit untuk bisa berkembang dan bersosialisasi dengan baik, hal tersebut terjadi karena ada tekanan pada diri anak, yang terkadang disebabkan oleh pertengkarana antara ibu dan ayah yang selalu mereka dengar. Apabila hal tersebut terjadi maka bisa dikatakan bahwa sekolah pertama bagi seorang anak tersebut "rusak". Jika sekolahnya telah rusak maka anak didiknya pun akan ikut rusak bahkan hancur.

Tentu hal ini merupakan hambatan terbesar bagi pendidik PAUD untuk mengembangkan jasmani, rohani dan akal mereka. Jadi partisipasi orangtua terhadap program parenting harus benar-benar di kuatkan oleh lembaga PAUD, bentuk penguatan tersebut bisa dengan menjalin kerjasama antara pihak PAUD dengan lembaga kesehatan, ahli gizi, lingkungan sekitar dan masyarakatnya.

\section{b. Partisipasi Orangtua disekolah dan dirumah}

Jumlah orangtua yang senantiasa mengantar anak nya ke sekolah atau lebih tepatnya mengantarkan anak ke lembaga PAUD saat ini tidaklah sedikit, ada beberapa faktor memang anak harus di antar oleh orangtuanya ke lembaga PAUD salah satunya adalah anaknya yang rewel, anaknya yang tak mau jauh dari orangtuanya, ataupun karena anak tersebut memang masih kecil jadi memerlukan perhatian lebih dan bahkan akan 
menimbulkan kekhawatiran jika dibiarkan berangkat sekolah sendirian, dan terkadang ada anak yang merasa nyaman ke sekolah jika berangkatnya dia antar sama orangtuannya. Kehadiran orangtua disekolah meskipun tidak formal secara otomatis telah menjalin kontak dengan guru-guru dilembaga PAUD tersebut. Dengan demikian jalinan komunikasi antara guru dan pihak orangtua dapat berlangsung dengan baik sehingga bermanfaat bagi tumbuh kembang anak. Atau bahkan komunikasi yang seperti itu akan membuka kerjasama anata guru dan orangtua dimana hasilnya merupakajn pengalaman pendidikan yang baik bagi anak.

Menjadi seorang guru PAUD ada baiknya jika selalu melibatkan orangtua dalam pendidikan anak, termasuk yang dilaksanakan disekolah. Dan keterlibatan orangtua ini perlu adanya dorongan dari pihak lembaga dan gur karena dapat membatu gur untuk membangun hargadiri guru di hadapan anak dalam menanamkan kedisiplinan dan mengurangi hambatan hambatan lainnya serta diharapkan dapat meningkatkan kesadaran anak untuk belajar.

Hasil-hasil riset menunjukan bahwa pencapaian anak meningkat dengan adanya program keikutsertaan orangtua di dalam sekolah (Suyadi :159).

Handerson (Suyadi :159) menyimpulkan bebrapa hal berikut ini.

1. Keluarga bukanlah sekolah yang menyediakan lingkungan pendidikan utama bagi anak.

2. Keterlibatan orangtua dalam pendidikan formal anak meningkatkan pencapaian belajar anak.

3. Keterlibatan orangtua adalah lebih efektif jika dilakukan secara komperenship dan berancana.

\section{c. Indikator/Keberhasilan Partisipasi}

Indikator keberhasilan peningkatan partisipasi dalam pendidikan dapat kita ukur melalui:

1. Kontribusi yang diberikan akan senantiasa meningkat seperti kontribusi berupa jasa, finansial, moral maupun material.

2. Meningkatnya kepercayaan orangtua/stakholders terhadap pihak sekolah.

3. Meningkatnya rasa tanggungjawab orangtua/stakholders terhadap program yang selenggerakan oleh pihak sekolah.

4. Meningkatnya masukan dan saran yang berkualitas sehingga dapat meningkatkan mutu pendidikan.

Berdasarkan uraian tersebut di atas dapat disimpulkan bahwa indikator keberhasilan partisipasi adalah meningkatnya saling pengertian dan saling membantu antara stakeholders terutama dalam setiap peningkatan mutu yang dilakukan oleh sekolah dan masyarakat.

\section{d. Faktor-Faktor Terbentuknya Partisipasi Orangtua}

Salah satu faktor terbentuknya partisipasi orangtua adalah Faktor kebutuhan orangtua itu sendiri dalam proses pendidikan, alasan individu bisa melakukan partisipasi didasari oleh berbagai macam motivasi dan kebutuhan. Kebutuhan yang berkaitan 
dengan upaya manusia untuk mempertahankan dan mengembangkan kehidupannya disebut kebutuhan hidup manusia.

\section{Konsep Pendidikan Anak Usia Dini (PAUD) \\ 1. Pengertian PAUD}

PAUD merupakan bentuk pendidikan yang sangat penting guna menyiapkan generasi yang berkualitas dimasa yang akan datang. Usia anak dari 0 s.d 6 tahun sebagai masa tumbuh kembang fisik dan psikis anak, sehingga usia ini seringkali sebagai masa golden age. PAUD merupkan masa menyiapkan anak ke jenjang pendidikan dasar dalam meletakan dasar kearah tumbuh kembang anak baik fisik, kecerdasan, sosial, emosional, bahasa dan berkomunikasi, serta bakat dan potensi lainnya yang dimiliki anak. Setiap orang dewasa (tidak terbatas orangtua) dituntut memiliki kemampuan dalam mendidik anak yang benar. Oleh karena itu kepedulian dan partisipasi masyarakat sangatlah penting dalam mensukseskan PAUD (Anwas, 2014 : 188). Jadi PAUD merupakan sarana untuk menggali dan mengembangkan potensi anak agar dapat berkembang secara optimal baik dari segi akhlaknya, perilakunya, sikap dan mentalnya.

\section{Tujuan PAUD}

a. Menentukan sejarah anak selanjutnya

Karena PAUD menjadi pondasi dasar keperibadian anak. Anak yang mendapatkan pembinaan yang tepat dan efektif sejak usia dini akan memiliki daya tahan tubuh serta kesejahteraan fisik dan mental yang baik sehingga dapat meningkatkan prestasi belajar, etos kerja, dan produktivitas yang mampu menjadikan anak mandiri dan mampu mengoptimalkan potensi yang dimilikinya.

b. Memberikan stimulasi atau rangsangan bagi perkembangan potensi anak

Memberikan stimulasi atau rangsangan bagi perkembangan potensi anak agar menjadi manusia beriman dan bertaqwa kepada tuhan yang maha esa, berakhlak mulia, sehat berilmu dan menjadi warga negara yang demokratis yang bertanggung jawab (Suyadi : 19). Dalam hal ini berarti PAUD memiliki fungsi untuk dapat mengembangkan potensi anak sertaa membentuk karakter dengan tujuan dapat bermanfaat bagi dirinya sendiri dan oranglain sehingga mampu mencerdasakan kehidupan anak bangsa yang taat terhadap tuhan yang maha esa. Dengan demikian apabila keadaan jasmani dan rohani nya sudah terpenuhi secara optimal maka tidak ada lagi penyimpangan-penyimpangan yang ditimbulkan karena sudah memiliki tujuan hidup yang jelas. Sehingga aspek yang tak boleh ditinggalkan adalah penguatan agamanya, karena itu menjadi dasar akidah yang lurus sesuai dengan agama yang dianutnya.

\section{Ruang Lingkup Lembaga PAUD}

Ruang linggkup lembaga PAUD terbagi menjadi 3 jalur, yaitu : jalur formal, jalur nonformal, dan jalur informal dan ketiganya merupakan jenjang pendidikan yang dilaksanakan sebelum pendidikan dasar. PAUD Jalur pendidikan formal diselenggerakan pada Taman Kanak-Kanak (TK), Raudhatul Athfal (RA), atau bentuk lain yang sederaat yang rentang usianya 4-6 tahun. Selanjutnya AAUD jalur pendidikan 
nonformal diselenggerakan pada Kelompok bermain (KOBER) yang rentang usianya 2-4 tahun. Kemudian PAUD jalur pendidikan informal, diselenggerakan pada TamanPenitipan Anaku (TPA) yang rentang usianya 3 bln-2 tahun atau satuan PAUD sejenis (SPS) yang rentang usianya 4-6 tahun

\section{Manajemen lembaga PAUD}

a. Kegiatan awal tahun

Pada awal tahun pihak lembaga membuka penerimaan murid baru, kemudian mendata murid, pendataan tersebut bermaksud untuk menjalin kerjasama dengan orangtua guna mengetahui latar belakang kehidupan anak. Pihak lembaga membagikan semacam angket partisipasi orangtua dengan maksud untuk mendapatkan gambaran tentang tipe orangtua apakah orangtua itu mau berperan langsung atau justru bersifat pasif karena keterbatasan waktu yang dimilikinya selain itu pihak lembaga memberikan penjelasan mengenai kegiatan yang ada disekolah baik dalam bidang akademik dan non akademik.

\section{b. Kegiatan pertengahan tahun}

Mengedarkan surat kabar sekolah berisi seputar aktivitas dan kegiatan yang akan diseenggerakan sekolah dengan maksud memberi tahu orangtua anak. Laporan perkembangan anak baik bersifat mingguan, bulanan maupun semester, itu merupakan suatu cara yang digunakan sekolah agar orangtua dapat mengetahui perkembangan anaknya dan membantu proses belajar serta orang tua dapat bekerjasama untuk memotivasi belajar anak .

c. Kegiatan akhir tahun

Rapat internal wali kelas dengan orangtua murid, pertemuan ini biasanya diadakan pada saat akhir semester diamana guru mrnyampaikan laporan tertulis tentang perkembangan siswa (Buku raport).

Berwisata bersama dengan melibatkan guru dan orangtua murid, dengan maksud tetap menjalin silaturahmi antara guru, murid, orangtua, dan pihak lembaga.

\section{d. Pelaksanaan}

Dalam tahap ini orangtua dan pihak lembaga sudah terlibat langsung dalam programprogram PAUD yang telah dirancang. Dalam pelaksanaanya mungkin hanya memerlukan waktu beberapa jam, hal tersebut tergantung pada kebutuhan. Dalam melaksanakan program-program tersebut juga memerlukan teknik pelaksanaan atau aplikasi dari setiap program tersebut, jangan sampai program-program tersebut hanya dirancang namun pelaksanaanya tidak sesuai atau tidak mencapai tujuan seharusnya dicapai dalam program tersebut. Suatu pelaksanaan membutuhkan kemampuan dan keterampilan tersendiri diantaranya keterampilan, mengelola kepemimpinan, praktek dalam setiap tahap kegiatan.

Dalam menjalankan dan melibatkan orangtua dalam lembaga PAUD agar dapat berjalan dengan optimal diantaranya : 
1) Tetap berpegang pada perencanaan yang telah dibuat

2) Pihak-pihak yang terlibat harus mempersiapkan diri dalam menjalankan tugasnya

3) Semua kebutuhan harus dipersiapkan dari awal

4) Seandainya perlu, lakukan gladi resik

5) Harus peka terhadap segala kemungkinan yang terjadi

6) Lakukan koordinasi lapangan dan penanggungjawab dalam pengambilan keputusan yang diperlukan

7) Jangan mengabaikan masalah-masalah kecil yang terjadi.

e. Evaluasi

Untuk melihat efektifitas dan efisien program hubungan sekolah dan orangtua, diperlukan evaluasi. Evaluasi adalah suatu proses kegiatan penilaian terhdap kegiatankegiatan yang berjalan dan terhadap hasil yang dicapai.evauasi juga menjadi tolak ukur untuk mengingkatkan mutu dan kualitas pendidikan. Dengan begitu semua masukanmasukan diharapkan dapat mengingkatkan pengelolaan hubungan orangtua dan sekolah.

Implikasinya didalam kolaborasi guru dan orangtua adalah :

1) Terlaksana atu tidak suatu perencanaan

2) Tercapai atau tidaknya tujuan kolaborasi

Cara melakukan evaluasi program keterlibatan orangtua di lembaga PAUD yaitu melakukan review kegiatan secara menyeluruh baik sebelum, sedang dan sudah program dilakukan, evaluasi ini dapat dilakukan baik secara formal maupun informal.

\section{METODE PENELITIAN}

Penelitian ini menggunakan metode deskriptif dengan pendekatan kualitatif sehingga akan menghasilkan data deskriptif berupa kata- kata tertulis atau lisan dari orangorang dan perilaku yang dapat diamati. Artinya data yang dianalisis di dalamnya berbentuk deskriptif dan tidak berupa angka- angka seperti halnya pada penelitian kuantitatif.

Sesuai dengan judul yaitu Optimalisasi Partisipasi Orangtua Melalui Program Parenting Di Lembaga Paud Srikandi maka penelitian ini menggunakan metode kualitatif karena mendeskripsikan, menguraikan dan menggambarkan tentang permasalahan yang akan dibahas yang berkenaan dengan proses, pelaksanaan, hambatan-hambatan sampai hasil.

Adapun alasanya dalam menggunakan pendekatan kualitatif karena peneliti ingin mengetahui dan memahami tentang strategi apakah yang dilakukan pengelola dalam optimalisasi partisipasi orangtua melalui program parenting secara akurat dan faktual sesuai dengan situasi yang sedang dialami, apakah sudah berjalan sesuai dengan yang telah direncanakan ataupun belum, sehingga diperlukan data data untuk mengetahui keadaan tersebut sesuai dengan keadaan yang ada. 
Dari alasan ini penelitian kualitatif dipilih oleh peneliti karena sesuai dengan tujuan kegiatan penelitian, yang diharapkan dapat berjalan secara alami serta memperoleh data-data yang objektif dan mendalam. Sedangkan Pengolahan data dengan cara deskriptif, menceritakan lewat kata-kata yang didapat di lapangan.

\section{Lokasi Penelitian}

Lokasi penelitian PAUD Srikandi terletak di Jl. KH. Usman Dhomiri kel. Padasuka kota Cimahi, lokasi tersebut di pilih karena memiliki program pendidikan anak usia dini (PAUD) untuk melaksanakan sebuah langkah awal dalam membantu pemerintah untuk memefasilitasi kebutuhan masyarakat yang memiliki anak balita, agar tetap dapat memberikan pendidikan yang layak bagi putra putrinya walaupun dengan kondisi serba kekurangan. Selain itu dengan peran pengelola yang senantiasa mampu bekerjasama dengan anggota dan orangtua siswa sehingga mampu mempertahankan keberadaan PAUD itu sendiri dengan menggunakan berbagai strategi.

\section{Partisipan}

Dalam penelitian ini subjek penelitian yang dipilih adalah orang-orang yang terlibat langsung pada kegiatan PAUD, antara lain :

a. Pengelola PAUD

b. Sekretaris

c. Bendahara

d. Tutor

e. Orangtua Siswa

\section{Populasi dan Sampel}

Populasi adalah wilayah generalisasi yang terdiri atas objek/subjek yang memiliki karakteristik tertentu sesuai dengan yang ditetapkan oleh peneliti untuk dipelajari dan kemudian di tarik kesimpulannya (Sugiyono, 2014:80).

Menurut Spardley (Sugiyono, 2014:215) populasi itu dinamakan social situation atau situasi sosial yang terdiri atas tiga elemen yakni, tempat, pelaku dan aktivitas yang berlaku secara sinergis. Situasi sosial tersebut bisa terjadi di dalam rumah berikut keluarga dan aktivitasnya, orang-orang yang sedang mengobrol di cafe, atau di tempat kerja, di kota, di desa, atau wilayah suatu negara.

Jadi populasi atau situasi sosial itu merupakan suatu objek penelitian yang ingin diketahui " apa yang terjadi” di dalamnya, dan yang menjadi populasi bukan hanya orang, tetapi bisa sebuah objek atau benda benda alam lainnya seperti tempat, pelaku, serta aktivitas yang yang berlaku secara sinergis. Kemudian dalam penelitian ini penulis mengambil sampel dari populasi yang dilakukan kepada orangtua PAUD Srikandi.

Sampel dalam penelitian ini memerlukan sejumlah orang yang harus kita teliti, dan yang ideal nya kita menyelidiki secara keseluruhan, namun apabila populasinya terlalu besar maka cukup dengan mengambil sampel yang representatif. Hal ini sesuai yang di ungkapkan dalam (Sugiyono, 2014:81) bahwa sampel merupakan bagian dari jumlah dan karakteristik yang dimiliki oleh populasi. Jadi hal tersebut terjadi apabila populasi terlalu besar, dan peneliti tidak mungkin mempelajari semua yang ada karena keterbatasan dana, tenaga, dan waktu, maka peneliti menggunakan sampel yang 
diambil dari populasi itu dengan catatan sampel yang diambil dari populasi harus betulbetul representatif (mewakili).

\section{Instrumen Penelitian}

Suatu penelitian memerlukan data atau informasi yang berguna untuk bahan pemecahan masalah yang ditemukan dalam penelitian tersebut. Untuk itu perlu teknik pengumpulan data yang tepat, agar penelitian mencapai tujuan yang diinginkan.

Adapun teknik yang digunakan penulis untuk mengumpulkan data dalah sebagai berikut:

\section{a. Observasi}

Observasi merupakan langkah awal yang dignakan untuk mendapatkan permasalahan atau kebutuhan, yang pada akhirnya dari hasil observasi tersebut menghasilkan teori dan pengetahuan baru. Dalam proses observasi peneliti banyak belajar mengenai perilaku dan keadaan serta makna yang tersirat dari perilaku atau keadaan yang terjadi.

Jadi dari penjelasan mengenai observasi tersebut, peneliti datang ke tempat kegiatan yang diamati serta mengumpulkan data dan ikut berpartisipasi dalam beberapa kegiatan, namun tidak semuanya. Dan pada awal observasi menyatakan kepada pengelola serta mengajukan permohonan ijin untuk bisa melakukan penelitian pada PAUD Srikandi.

b. Wawancara

Wawancara merupakan salah satu teknik pengumpulan data yang dilakukan oleh peneliti dalam suatu bentuk komunikasi sehingga terjadi interaksi yang bertujuan untuk memperoleh informasi.

c. Study kepustakaan,

Study kepustakaan merupakan suatu teknik pengumpulan data yang diperoleh dari buku, dokumen-dokumen dan catatan yang sesuai dengna masalah yang sedang diteliti.

d. Penelitian lapangan,

Merupakan teknik pengumpulan data secara langsung, dimana seorang peneliti ikut terlibat terhadap masalah yang sedang diteliti.

\section{HASIL PENELITIAN DAN PEMBAHASAN}

Berdasarkan hasil penelitian mengenai partisipasi orangtua terhadap pengelolaan pendidikan anak usia dini, hasil temuan penelitian dapat dipaparkan sebagai berikut :

\section{Hasil Penelitian}

a. Profil Sekolah

1) Sejarah pendirian

Keberhasilan pelaksanaan pembangunan nasional di bidang pendidikan non formal sangat di tentukan oleh dukungan dan peran serta masyarakat. Keterlibatan masyarakat dalam proses pendidikan secara tidak langsung akan memeberikan keleluasaan bagi masyarakat dalam menentukan masa depannya, agar dapat menjadi masyarakat yang mandiri,serta dapat meningkatkan tarap hidupnya. Hasil pendataan yang kami lakukan 
disetiap tahun memberikan sebuah gambaran bahwa masih terdapat keluarga miskin yang tidak mampu memfasilitasi pendidikan yang layak bagi putra putrinya. Data ini menunjukan perlu uluran tangan dari lembaga-lembaga masyarakat untuk ilkut perduli dalam memefasilitasi kebutuhan masyarakat salah satunya dibidang pendidikan.

Melaui program pendidikan anak usia dini (PAUD) yang kami laksanakan adalah sebuah langkah awal dalam membantu pemerintah untuk memefasilitasi kebutuhan masyarakat yang memiliki anak balita, agar tetap dapat memberikan pempididkan yang layak bagi putra putrinya walaupun dengan kondisi serba kekurangan. Jadi intinya PAUD Srikandi ini didirikan untuk memfasilitasi masayarakat yang kurang mampu supaya putra putri mereka bisa tetap mendapatkan pendidikan.

2) Visi dan Misi Lembaga

VISI

"Mewujudkan anak yang Sehat, Cerdas.Terampil, Berakhlak Mulia dan Mandiri"

MISI

a) Menciptakan suasana bermain dan belajar yang menyenangkan,

b) Memeberikan pelayanan pendidikan melaui konsep bermain , pada anak,

c) Mengembangkan potensi dan kreatifitas anak secara optimal,

d) Menumbuhkan kemandirian pada anak.

MAKSUD DAN TUJUAN

a) Untuk merespon keinginan masyarakat yang tidak mampu untuk peduli terhadap pendidikan, agar dapat mandiri sesuai karakter, situasi lingkungan dan kondisi masyarakat tersebut.

b) Memberikan pelayanan pendidikan pada anak usia dini yang berasal dari keluarga tidak mamapu, yang tidak dapat memasukan anaknya ke TK dengan biaya pendidikan yang relative mahal.

c) Membantu pemerintah dalam menanggulangi kebutuhan masyarakat pada dunia pendidikan terutama untuk anak usia dini.

Menurut kepala sekolah saat ini PAUD srikandi sedang mengalami penurunan peserta didik, yang disebabkan sudah menjamurnya pendidikan PAUD pada tiap wilayah, sehingga banyak masyarakat yang menyekolahkan anak-anaknya ke sekolah yang lebih dekat.

Tahun ajaran 2014 jumlah peserta didik 21 siswa

Tahun ajaran 2015 jumlah peserta didik 36 siswa

Tahun ajaran 2016 jumlah peserta didik 22 siswa dan

Tahun 2017/2018 jumlah peserta didik 16 siswa.

PAUD srikandi ini dapat terus berjalaan karena keridhoan Allah swt, yang senantiasa menguatkan kepala sekolah, staf dan guru, sehingga dengan kerja keras yang maksimal dari berbagai pihak tersebut PAUD ini masih berjalan seperti biasanya, meskipun tak sedikit hambatan yang senantiasa menyerang PAUD ini, namun karena tujuan awal dari berdirinya PAUD ini untuk membantu dan memfasiliatsi masyarakat yang kurang 
mampu agar anak-anaknya tetap bisa merasakan pendidikan apapun hambatannya PAUD ini sampai sekarang masih berjalan dengan normal. Sehingga mampu menamatkan siswa-siswanya yang kemudian mereka bisa melanjutkan ke SD.

\section{3) Pengelolaan PAUD}

Pengelolaan PAUD Srikandi merupakan pengelolaan mandiri yang diserahkan sepenuhnya kepada pengurus lembaga, dengan latarbelaknag sumberdaya manusia yang terlibat didalamnya maka PAUD Srikandi menggunakan jenis Pengelolaan Partisipatif yang memberikan kesempatan kepada setiap sumber daya yang ada untuk ikut berperan serta dalam kegiatan yang dilakukan oleh lembaga PAUD tersebut.

PAUD ini terbuka dari mulai kegiatan perencanaan, kemudian pengorganisasian, pelaksanaan kegiatan serta pengawasan kegiatan. Dengan begitu siapapun yang ada dalam lembaga PAUD ini dapat mengikuti kegiatan lembaga dari mulai direncanakan sampai akhirnya dilakukan pengawasan dan evaluasi kegiatannya. Seperti halnya pada program parenting pengelolaan nya pun melibatkan semua aspek yang ada di PAUD Srikandi, dari mulai pembuatan undangan, penyebaran sampai pelaksanaan dan evaluasi.

a) Partisipasi orangtua dalam pengelolaan PAUD

Partisipasi orang tua anak usia dini yang ada pada lembaga PAUD Srikandi partisipasi dengan pembayaran SPP dan memberikan atau menyumbangkan tenaga dalam kegiatan lembaga PAUD, cara ini banyak digunakan oleh orang tua anak usia dini yang bisa terlibat.

b) Kendala orangtua dalam partisipasi pada pengelolaan PAUD

Faktor yang menjadi kendala dalam partisipasi orang tua pada pengelolaan lembaga PAUD yang paling tinggi adalah faktor waktu. Faktor waktu inilah yang menjadi penentu bisa atau tidaknya orang tua terlibat dalam kegiatan yang memberikan kesempatan untuk berpartisipasi. Selanjutnya faktor materi atau uang, banyaknya orang tua yang merasa tidak memiliki materi berlebih menyebabkan keterbatasan dan menjadi kendala untuk turut berpartisipasi dalam kegiatan pengelolaan lembaga PAUD. Selanjutnya adalah jarak yang lumayan jauh jika ditempuh, menyebabkan orangtua untuk enggan datang pada tiap program parenting. Faktor terakhir adalah tidak pahamnya orang tua anak usia dini mengenai pengertian, tujuan, esensi dan inti dari pendidikan anak usia dini, hal ini menyebabkan orang tua lebih mempercayakan setiap kegiatan anaknya pada lembaga PAUD tanpa mau terlibat langsung. Selain itu juga faktor berkurangnya partisipasi orangtua terhadap PAUD Srikandi adalah telah maraknya PAUD di sekitar daerah tersebut, yang menyebabkan menurunnya jumlah peserta didik. Hingga akhirnya dari beberapa faktor kendala yang ada pihak pengelola memberikan strategi khusus kepada orang tua siswa untuk menimbulkan ketertarikan atau keinginan melakukan partisipasi orangtua terhadap lembaga PAUD yakni berupa kegiatan parenting yang di adakan oleh pihak lembaga yang nantinya dalam kegiatan parenting tersebut ada berbagai kegiatan yang diikuti oleh orangtua sehingga diharapkan dapat terjalin komunikasi antara pihak lembaga dan pihak pengelola tanpa adanya suasana yang kaku dan orangtua dapat menyampaikan keluhannya dengan ringan tanpa adanya suatu beban kemudian orangtua yang lainnya pun dapat 
mensosialisasikan keberhasilan PAUD yang pada akhirnya banyak orangtua yang mensekolahkan anak-anaknya ke PAUD Srikandi.

\section{Pembahasan}

H.A.R.Tilaar, (2009: 287) mengungkapkan partisipasi adalah sebagai wujud dari keinginan untuk mengembangkan demokrasi melalui proses desentralisasi dimana diupayakan antara lain perlunya perencanaan dari bawah (bottom-up) dengan mengikutsertakan masyarakat dalam proses perencanaan dan pembangunan masyarakatnya. Mengikitsertakan masyarakat atau orangtua dalam proses perencanaan merupakan hal yang penting yang bertujuan untuk memberi pengetahuan dan informasi kepada masyarakat atau orangtua terhadap hal apa saja yang akan dilakukan sehingga orangtua mampu menyampaikan ide dyang muncul dan informasi terhadap kemungkinan terjadinya beberapa masalah, artinya partisipasi adalah keikutsertaan masyarakat dalam memecahkan suatu permasalahan dalam bentuk penyampaian saran dan pendapat, barang, keterampilan, bahan dan jasa ataupun yang lainnya yang bisa di sampaikan kepada pihak lembaga.

Namun berdasarkan hasil penelitian dan observasi di lembaga PAUD Srikandi, partisipasi orangtua sangatlah kurang, terutama partisipasi dalam program parenting. Padahal telah kita ketahui bersama program parenting merupakan salah satu hal yang penting terhadap kembaga PAUD, karena dengan adanya program parenting dapat menimbulkan komunikasi yang terjalin antara pihak orangtua dan lembaga sehingga keikutsertaan orangtua dalam memecahkan suatu permasalahan dalam bentuk penyampaian saran dan pendapat, barang, keterampilan, bahan dan jasa ataupun yang lainnya pun dapat teralisasikan. Kebanyakan penyebab dari kurangnya partisipasi orangtua di PAUD srikandi pun akibat lemahnya kondisi ekonomi mereka, sehingga para orangtua lebih memilih mencari pendapatan ekonomi. Ditambah lagi saat ini PAUD Srikandi lokasinya pindah yang awalnya di komplek PJKA sekarang di Jl. KH. Usman Dhomiri. Hal tersebut menjadikan banyak orangtua yang mengeluhkan akan jarak, karena kebanyakan dari orangtua siswa jalan kaki ketika akan pergi ke PAUD. Bahkan dalam kesehariannnya jumlah siswa yang mengikuti pembelajaran hanya 5-9 siswa dari data 16 siswa sejak berpindahnya lokasi PAUD hampir tidak pernah siswa yang berjumlah 16 orang tersebut masuk semua.

Program parenting di PAUD Srikandi pada tahun ini pula belum terlaksana kembali, sehingga hal tersebut semakin membuat berkurangnya partisipasi orangtua terhadap PAUD Srikandi. Namun demikian, dengan telah tersedianya program yang difasiliasi oleh PKBM Srikandi diharapkan dapat mendukung kemandirian masyarakat dalam mengembangkan dan meningkatkan standar kualitas pendidikan terutama pendidikan anak usia dini di kota Cimahi, karena proses pemberdayaan melalui pendidikan tidak hanya bergerak dalam bidang pendidikan semata, melainkan dengan dasar membangun kemandirian dan mendorong pemanfaatan kekuatan modal sosial (social capital) dalam rangka mendukung pembangunan masyarakat berkelanjutan (Mulyono, 2018)

\section{E. KESIMPULAN}

Berdasarkan pembahasann tersebut maka dapat di simpulkan bahwa pengelolaan PAUD Srikandi merupakan pengelolaan mandiri yang diserahkan sepenuhnya kepada pengurus lembaga, dengan latarbelaknag sumberdaya manusia yang terlibat 
didalamnya maka PAUD Srikandi menggunakan jenis Pengelolaan Partisipatif yang memberikan kesempatan kepada setiap sumber daya yang ada untuk ikut berperan serta dalam kegiatan yang dilakukan oleh lembaga PAUD tersebut. PAUD ini juga terbuka dari mulai kegiatan perencanaan, kemudian pengorganisasian, pelaksanaan kegiatan serta pengawasan kegiatan. Dengan begitu siapapun yang ada dalam lembaga PAUD ini dapat mengikuti kegiatan lembaga dari mulai direncanakan sampai akhirnya dilakukan pengawasan dan evaluasi kegiatannya. Seperti halnya pada program parenting pengelolaan nya pun melibatkan semua aspek yang ada di PAUD Srikandi, dari mulai pembuatan undangan, penyebaran sampai pelaksanaan dan evaluasi

Kemudian dalam pengoptimalisasian partisipasi orang tua lembaga membuat strategi untuk membuat orangtua ikut berpasrtisipasi. Dan salah satu strategi yang digunakan yaitu program parenting yang di barengi dengan kegiatan masak memasak. Strategi tersebut satu tahun kebelakang selalu terealisasikan dan responnya pun positif, namun kembali lagi akibat pindahnya lokasi lembaga PAUD dan kesibukan para orangtua untuk tahun ajaran sekarang maka program parenting belum terlaksana.

Maka dengan adanya strategi yang telah dilakukan untuk membuat orangtua ikut berpartisipasi yang baik antara pihak keluaraga dan orangtua sehingga akan terjalin komunikasi yang kedepannya dapat memudahkan pihak lembaga untuk lebih meningkatkan mutu pendidikannya baik dari segi kualitasnya ataupun dari segi kuantitasnya. namun salah satu contoh strategi pengotimalisasian partisipasi orangtua melalui program parenting mungkin saat ini masih dirasa kurang. Dan Jika dilihat dari faktor-faktor yang mempengaruhi kurangnya partisipasi orangtua maka ada baiknya melakukan pendekatan personal dari pihak tutor ataupun lembaga kepada para orangtua, sehingga ketika akan melaksanakan program parenting yang bertujuan untuk menciptkan komunikasi dengan orangtua tersebut diharapkan akan lebih meningkat akan terwujud. Terlepas dari itu semua pihak lembaga dan tutor pun harus senantiasa optimis akan setiap halangan yang menerjang, karena allah takan memberikan suatu beban melebihi batas kemampuan manusia.

\section{F. DAFTAR PUSTAKA}

Anwas, Oos M, 2014. Pemberdayaan masyarakat di era global. Bandung. Alfabet HAR, Tilaar. 2009. Paradigma Baru Pendidikan Nasional. RinekaCipta: Jakarta

Jalal, Fasli dan Dedi Supriadi, 2001, Reformasi Pendidikan Dalam Konteks Otonomi Daerah, Yogyakarta: Adicita Karya Nus

Juknis penyelenggaraan PAUD

Jurnal Ilmu Pendidikan dan Pengajaran, Vol. 2 No. 1, Maret 2015

Kiam. 2014. Implementation of early childhood education (PAUD) policies in Sintang subdistrict. Jurnal administrasi dan birokrasi, Vol. 1 no.1, 2014, artikel 3. Hal 1.

Kintamani ida, 2015, perkembangan pendidikan tahun 2008/2009-2013/2014. Jakarta Pusat Data dan Statistik Pendidikan dan Kebudayaan.

Mulyono, D. 2018. THE STRATEGY OF MANAGERS IN MOVING BUSINESS LEARNING GROUP PROGRAM IN PKBM SRIKANDI CIMAHI CITY. Journalof Educational Experts (JEE) Vol. 1 (1), 41-50

Widiastuti, N., P. Kartika. 2017. Penerapan model kelompok usaha kreatif islami (KUKIS) dalam pemberdayaan perempuan berbasis pondok pesantren. Jurnal empowerment Vol 6, nomor 2 Oktober 2017. 
Suyadi, 2012. Konsep dasar PAUD. Bandung. PT Remaja Rosdakarya

Siti Irene Astuti Dwiningrum. 2011. Desentralisasi dan Partisipasi Masyarakat dalam Pendidikan. Yogyakarta: Pustaka Pelajar

Sudjana, 2010, Metode Dan Teknik Pembelajaran Partisipatif, Falah

Sugiyono, 2014, Metode Penelitian Kuantitatif Kualitatif Dan R\&D, Alfabeta, Bandung, Teori Pendidikan Anak Usia Dini [Online] Tersedia : Pustakamateri.web.id ( 12 Oktober 2017 ) 